УДК 378.016:81

DOI:

Алла Моренцова, викладач кафедра англійської мови технічного спрямування №1 Факультет Лінгвістики Національний технічний університет України "Київський політехнічний інститут імені Ігоря Сікорського”

\title{
МОТИВАЦЙНІ АСПЕКТИ ВИВЧЕННЯ АНГЛІЙСЬКОЇ МОВИ ЯК ІНОЗЕМНОЇ В ЕПОХУ ГЛОБАЛІЗАЦІї
}

У статті розглядаються різноманітні фактори, які впливають на мотивацію навчання іноземнихмов. Зазначається, щฺо мотивація до вивчення англійської мови стає дедалі більш особистісним питанням. Розглядається важливість активної та свідомої участі студентів у підвищенні ефективності власного навчання. Зауважується, щз індивідуальні варіанти мотивації, розглянуті в статті, забезпечують корисний досвід, який можна застосувати для підвищення мотивації у процесі вивчення англійської мови. Зроблено висновок, щчо необхідно звертати особливу увагу на навчальні стратегії, покликані забезпечити високу ефективність навчального прочесу, зокрема, шляхом підвищення рівня навчальної мотивачії студентів.

Ключові слова: англійська мова; іноземна мова; мотивація; навчальні стратегії; досвід вивчення.

Лim. 13.

Alla Morentsova, Lecturer, Technical English Department No.1, Linguistics Faculty National Technical University of Ukraine "Ihor Sikorskiy KPI"

\section{MOTIVATIONALASPECTS OF LEARNING ENGLISH AS A FOREIGN LANGUAGE IN ERA OF GLOBALIZATION}

The intent of this article was to focus attention of the variety of factors influencing motivation in foreign language learning. This study also raises interesting questions about finding clearer links between motivational factors and specific choices of learning strategies. Some possibilities for the future have been noted, but more work in that area is needed. It was noted that motivation to learn English is becoming increasingly a personality issue. Considers the importance of active and conscious contribution of students to increasing the effectiveness of their own learning is considered. However, everybody knows that keeping students motivated in foreign language Learning is not an easy task. Ukrainian university students who are motivated to learn English are more efficient at becoming fluent in English. Individual learners often have specific motivations with which they feel more comfortable. High motivation can cover up for significant deficiencies in both language skills and learning conditions. In the process of teaching a foreign language in modern conditions, the application of the Zeigarnik effect may be relevant. The essence of the Zeigarnik effect is that incomplete actions are remembered better than complete ones. The Zeigarnik effect is a significant source of reengagement motivation. Attitudes and motivation are closely related to success in foreign language learning. Learning strategies constitute a useful tool kit for active and conscious learning. Using a variety of activities can both create interest and allow for students to be successful through use of different types of learning strategies. Occasionally, even those strategies which are generally the most reliable ones, may not work with a particular group or in particular situations. The individual motivation options discussed in the article provide a rewarding experience that can be applied to increase the learning motivation of students in the process of learning English. It is concluded that it is necessary to pay special attention to learning strategies designed to ensure high efficiency of the educational process, in particular, by increasing the level of educational motivation of students of non-linguistic universities.

Keywords: English; Foreign Language; motivation; learning strategies; study experience.

П

остановка проблеми. Місія вищої освіти України полягає у забезпеченні стабільного конкурентоспроможного розвитку країни завдяки підготовці висококваліфікованих фахівців, набуття та поширення навичок, умінь та знань, інтелектуального, соціального і духовного зростання суспільства. Для прийняття рішень, які сприятимуть формуванню стабільного та готового до викликів майбутнього середовища освіти, визнається необхідність аналізу масштабних тенденцій. Організацією економічного співробітництва та розвитку (ОЕСР) розроблений звіт Trends Shaping Education 2019 на підтримку довгострокової стратегічної доктрини в освіті [11]. У ньому представлений огляд ключових економічних, соціальних, демографічних і технологічних тенденцій, піднімаються відповідні питання про їх вплив на освіту. Також у звіті наводяться три мегатренди, що впливають на майбутнє освіти: глобалізація, цифровізація, старіння населення. С всі підстави вважати, що безпрецедентна цифрова трансформація глобальної економіки і суспільства збільшить 


\section{МОТИВАЦЙНІ АСПЕКТИ ВИВЧЕННЯ АНГЛЙСЬКОӤ МОВИ ЯК ІНОЗЕМНОЇ В ЕПОХУ ГЛОБАЛІЗАЦІЇ}

складність сучасного світу, а також швидкість змін, в основному через розширення можливостей цифрових комунікацій і більшої кількості освічених людей у всьому світі. Ці два елементи складність і швидкість змін - означають, що “'зв'язок освіти з тенденціями, що формують світ, в якому ми живемо, ще ніколи не був таким актуальним" [11]. Актуальності набувають навички системного мислення, програмування, міжгалузевої комунікації, вміння працювати в умовах невизначеності, мультикультурність і володіння декількома мовами, екологічність мислення, мультифункціональність [6, 30]. У Стратегії розвитку вищої освіти в Україні на 20212031 рр., розробленій МОН України для закладів вищої освіти, формулюється завдання “поєднання розвитку таких здатностей у студентів та одночасного надання їм спеціалізованих знань i навичок у рамкам обраної професії' $[6,31]$. Такий підхід сприятиме у майбутньому формуванню безперервної освіти.

Аналіз основних досліджень і публікацій. Методикам навчання іншомовної мовленнєвої діяльності у вищих немовних закладах освіти та проблемам формування мотивації вивчення іноземної мови присвячено багато праць педагогічних працівників та науковців (Н. Арістова, Ф. Денисенко, М. Кабанова, Н. Підласий, О. Тарнопольський, О. Терещенко, О. Фіногенова та ін.).

О. Тарнопольський визнає розвиток високої навчальної мотивації важливим завданням викладача $[7,8]$. Він констатує, що успіх в оволодінні мовою слід уважати “цілком похідним від рівня розвитку позитивної навчальної мотивації тих, хто навчаються, та їхніх ефективних навчальних стратегій” [7, 9]. Він констатує, що викладач повинен “добре уявляти спектр інтересів студентів у академічній групі, які власні цілі вони ставлять перед собою, вивчаючи іноземну мову і в чому вони вбачають свої індивідуальні потреби у такому вивченні” [7, 41]. Цікавим видається застосування Ю. Корницькою технології “перевернутий клас" для більш активного залучення студентів до освітнього процесу та посилення мотивації [3, 116].

Дослідженням питань розвитку навчальної мотивації вивчення іноземних мов у різні часи займалися закордонні дослідники (М. Boekaerts, R. Burden, R. Gardner, Z. Dornyei, A. Wenden, M. Williams та ін.).

Відомий британський дослідник 3. Дорней у книзі "Психологія того, хто вивчає мову: індивідуальні відмінності в засвоєнні другої мови” припускає, що вивчення англійської мови у світовому масштабі стає помітною та особливою областю освіти, отже, через всеосяжну значимість "World English" в глобалізованому світі успіх зазначеного процесу частково залежатиме від усвідомлення себе громадянином світу [9, 118]. Дорней зазначає, що сьогодні важливість активного і усвідомленого внеску учнів у підвищення ефективності їх власного навчання $\epsilon$ актуальнішою, ніж будь-коли раніше [9, 195].

За спостереженням R. Nurhidayah, за умов достатньої мотивації “навіть люди з мінімальними здібностями зможуть досягти довгострокових цілей, і відповідна навчальна програма поряд 3 хорошим викладанням буде достатньою для забезпечення успішності” $[10,96]$. На іiі думку, високий рівень мотивації може компенсувати значні недоліки як у мовних навичках, так і в умовах навчання [10,97].

Питання про знаходження більш чітких зв'язків між мотиваційними чинниками і конкретним вибором стратегій навчання набувають нових контурів. За словами Дорнея, навіть якщо припустити, що особистісні фактори не визначають безпосередньо ступінь академічної успішності людини, то вони, безумовно, визначають те, як люди реагують на сферу навчання [9]. Та обставина, що англійська мова визнається ключовою компетентністю сучасної людини, змушує приділяти особливу увагу стратегіям їі навчання. Тому дослідження можливостей підвищення рівня навчальної мотивації зберігають свою актуальність.

Мета статті полягає у з'ясуванні можливостей підвищення рівня мотивації навчання іноземної мови студентів немовних закладів вищої освіти. Для розв'язання завдання статті було проаналізовано відкриті Інтернет-джерела, зокрема такий Інтернет-ресурс як Quora, який $є$ архівом запитань-відповідей, об'єднанних за темами. При роботі над статтею був використаний комплекс теоретичних методів, зокрема: аналіз, синтез, узагальнення та систематизація.

Виклад основного матеріалу дослідження. 32014 р. Британська Рада у партнерстві 3 Міністерством освіти та науки України проводили глибинне допроєктне дослідження в університетах всієї країни, щоб оцінити сучасний стан викладання англійської мови, а також роль і статус англійської мови в цих установах [1]. Як довготермінові цілі дослідження, розглядались досягнення трансформаційних змін у рівні володіння англійською мовою в провідних українських університетах та підвищення освітніх стандартів до рівня, “який дозволить іії учасникам 


\section{МОТИВАЦЙНІ АСПЕКТИВИВЧЕННЯ АНГЛІЙСЬКОЇ МОВИЯК ІНОЗЕМНОЇ В ЕПОХУ ГЛОБАЛІЗАЦЇ}

брати повноцінну участь у подіях на міжнародній арені” $[1,21]$. За результатами дослідження було рекомендовано, зокрема, визнати важливість англійської мови в наукових установах і для проведення досліджень, а також включити популяризацію викладання і вивчення англійської мови до національної стратегії. В 2019 р. Міністерством освіти і науки України було прийнято “Концепцію розвитку англійської мови в університетах", якою англійська мова визнавалась ключовою компетентністю сучасної людини та важливим інструментом міжнародного спілкування [2]. Для заохочення університетів до викладання і студентів до вивчення англійської мови прийнятою концепцією заплановано збільшення годин, внесення змін до змісту мовних дисциплін та введення відповідних іспитів [4, 605]. Слід зазначити, що за останні роки випуск фахівців із закладів вищої освіти України знизився. Так, з 2010 до 2019 р. випускників університетів, академій, інститутів стало менше на 38,6 \%, загальна кількість випускників 3ВО знизилася на 41,4 \%. Усе більше студентів відмовляються від подальшого навчання у магістратурі. Причини такої негативної тенденції - у зменшенні державного фінансування навчання, ускладненні вступу до магістратури із запровадженням обов'язкового ЗНО з англійської мови та виїзді для продовження навчання за кордон $[6,19]$. За вищезазначеною статистикою можна припустити, що рівень мотивації вивчення англійської мови серед українських студентів коливається від практично відсутньої мотивації до навпаки, найвищого рівня мотивації, який, зокрема, спонукає молодь продовжувати навчання за кордоном. Як констатується у Стратегії розвитку вищої освіти, “низькі можливості працевлаштування після закінчення ЗВО разом із незадовільною подекуди якістю освіти спонукають найбільш підготовлених, талановитих й амбітних молодих людей вступати до закордонних 3ВО” [6, 14]. 3 огляду на необхідність адаптації освіти до перетворень, що відбуваються в економічній, соціальній і технологічній сферах, слід прагнути, щоб освіта підтримувала людей в особистісному, громадянському та професійному розвитку. Необхідно приділити особливу увагу стратегіям навчання, покликаним забезпечити високу результативність навчального процесу, зокрема, шляхом підвищення рівня навчальної мотивації тих, хто навчаються.

Для досягнення поставленої мети статті, а саме з'ясування аспектів мотивації вивчення іноземної (англійської) мови як проявів індивідуальності / особистості людини звернімось до світового досвіду вивчення іноземних мов. Такий підхід можна виправдати тим, що Законом України "Про вищу освіту" вимагається узгодження програм викладання й вивчення іноземної мови в закладах вищої освіти 3 приведенням їх у відповідність до Загальноєвропейських рекомендацій з мовної освіти. Тому ситуація щодо формування у молоді різних країн мотивів вивчення іноземних мов становить певний інтерес та таке дослідження може бути корисним з огляду на загальні потреби й інтереси молодих людей.

Актуальну інформацію за зазначеною тематикою можна знайти на різних Інтернетpecypcax. Quora, заснований в червні 2009 р. соціальний сервіс обміну знаннями, своєрідний веб-сайт питань і відповідей, які об'єднані за темами, є вартим довіри Інтернет-джерелом. Користувачі Quora реєструються під своїми справжніми іменами, отже, дбають про свою репутацію і досить серйозно ставляться до своїх відповідей. Для розгляду пропонуються опитування, виконані для двох запитань: “Які Ваші мотиви вивчення нової мови?” та “Як Ви зберігаєте мотивацію при вивченні мови?” [12; 13]. Серед опитаних були американці, індійці, в’єтнамці, філіппінці, індонезійці, малайзійці, китайці, японці, турки, жителі Сингапура та Гонконга, поляки, греки, французи, корейці та інші. Питання щодо збереження мотивації виявилося найбільш актуальним, викликало підвищене зацікавлення серед зареєстрованих користувачів Quora i зібрало понад 100 відповідей, не враховуючи коментарі та відгуки до них. Не розглядаючи кожну відповідь окремо, можна з'ясувати певні загальні тенденції. Опитувані майже одностайно погоджуються, що дисципліна важливіша ніж мотивація. Також часто лунають думки, що “слід відмовитись від перфекціонізму”, “більше пишатися своїм прогресом, навіть у дрібницях”, не сварити себе, сприймати те, що засвоїли та зрозуміли як маленькі перемоги, не боятися робити помилки, “бути добрими до себе”. Дехто з опитаних зазначає, що “багато людей втрачають мотивацію, тому що вивчити нову мову складно, особливо, якщо немає важливої причини, реального пріоритету для цього, якщо немає дисципліни i терпіння, це просто стає скороминущим інтересом" [13]. Декілька опитаних незалежно один від одного надали майже однакові поради, які самі з успіхом перевірили на практиці. Суть цих порад полягає у тому, щоб розділити велику ціль на більш дрібні, взаємопов'язані цілі або етапи, щоб мати можливість скористатись прийомом для 
підтримки мотивації, який базується на такому психологічному принципі, як ефект незавершеної дії (або ефект Зейгарник). Для довідки: суть феномену полягає в тому, що людина краще запам'ятовує дію, яка залишилася незавершеною або завершення якої було відстрочено на деякий період часу. Доки завдання не закінчене, мотиваційна напруга підвищує ймовірність того, що питання збережеться в пам'яті. Психологи попереджають, що мотиваційна розрядка повинна бути лише відстрочена, але її наявність $є$ обов'язковою. Опитувані впевнені, що якщо хтось дійсно не хоче вчитись або недостатньо захоплений навчанням, то з усією впевненістю можна сказати, що він не зможе вивчити іноземну мову. Багато відповідей надали люди, захоплені вивченням іноземних мов. Вони пишуть: "Мені подобаються культури, які відрізняються від моєї, я хочу дізнатися більше про культури, яких я не знаю. У той же час я хочу, щоб більше людей могли більше та краще дізналися про мою країну. Отже, я вивчаю англійську, яка $є$ найбільш глобальною мовою в світі" [13]. Опитувані рекомендують читати або ознайомлюватись 3 літературою та публікаціями на іноземній мові, обираючи те, що подобається та не є надто складним на даному етапі вивчення мови. Серед тих, хто надав відповіді, багато поліглотів. Це ті, хто вивчив спочатку одну мову, потім через цікавість або необхідність ще одну, зрозумів, як це робиться і продовжує вивчати мови, які вважає цікавими для себе. "Багато, і дуже багато звичайних людей, які говорять на декількох мовах. Для цього не потрібно бути генієм" [13]. Один 3 опитаних зауважив, що коли б він продовжував жити в Америці, навряд чи він вивчив би стільки мов, як натепер, після переїзду до багатомовної Європи. Ще один з опитаних шкодує, що надто довго очікував, коли буде мотивований достатньою мірою та витратив багато часу дарма. В цій статті наводяться найбільш цікаві та типові відповіді на поставлені питання. Ще одне, досить характерне, висловлене твердження: “Мова - це засіб, за допомогою якого ви можете отримати нову інформацію. Вам подобається процес навчання, тому що ви використовуєте цю мову для отримання нової інформації і нових знань” [13].

Наведемо для порівняння деякі дані соціологічного опитування студентів, проведеного в НТУУ “КПI” [5]. Відповіді надавали студенти чотирьох курсів восьми факультетів та інститутів НТУУ “КПІ”. Розглянемо відповіді на запитання “Що для Вас особисто є головним мотивом при вивченні іноземної мови?”. Необхідність для кожної освіченої людини знати іноземну мову визнали своїм мотивом 30 \% опитаних. Ще 27 \% усвідомлювали важливість знань з іноземної мови для подальшої роботи. Близько 20 \% студентів визнали, що іноземна мова $є$ засобом задоволення їніх позаурочних інтересів. I тільки $16 \%$ вивчають ії як обов'язкову дисципліну, з якої хочуть мати хорошу оцінку або залік [5].

Якщо порівняти відповіді українських студентів та жителів інших країн, які вивчають англійську мову, то можна побачити єдність думок щодо свідомого вивчення англійської як важливого інструмента спілкування, необхідного для будьякої освіченої людини. Проте, незважаючи на наявність у частини студентів високого рівня мотивації, все ще залишається досить велика частка студентів, які або ще не усвідомлюють важливість вивчення мов, або апріорі вважають іноземну мову непотрібною для них.

Висновки 3 даного дослідження. Розглянуті вище варіанти формування мотивації надають корисний досвід, який може бути застосований для підвищення навчальної мотивації студентів у процесі опанування мов. Позитивна мотивація сприятиме особистісному розвитку та ефективній професійній підготовці кваліфікованих фахівців, для яких на сьогодні вміння розмовляти англійською є однією 3 найважливіших умов професійного спілкування та успішної роботи. Перспективною темою для подальших розвідок може бути дослідження освітнього потенціалу ефекту Зейгарник у викладанні англійської мови.

\section{ЛІТЕРАТУРА}

1. Болайто Р., Вест Р. Інтернаціоналізація українських університетів у розрізі англійської мови: Проект “Англійська мова для університетів". Київ: “Видавництво “Сталь”, 2017. 154 с.

2. Концепція розвитку англійської мови в Університетах. МOH України. 2019. URL: https:// mon.gov.ua/ua/news/mon-stvorilo-koncepciyu-rozvitkuanglijskoyi-v-universitetah-u-dodatku-riven-v1obovyazkova-umova-vstupu-v2-vipusku-vikladannyaprofilnih-disciplin-inozemnoyu-ta-movni-skriningi (дата звернення 28.04.2021).

3. Корницька Ю. Перевернутий клас в курсі англійської мови фахового спрямування: ставлення студентів. Молодь і ринок. Щомісячний науковопедагогічний журнал. Дрогобич, 2020. №. 1/180. С. 116-120.

4. Моренцова А.В. Самостійне екстенсивне читання адаптованих книг англійською мовою у немовних вищих навчальних закладах. Молодий вчений. 2020. № 4 (80), c. 605-608. DOI: https://doi.org/10.32839/2304-5809/ 2020-4-80-125

5. Саєнко Н.С. та ін. Моніторинг якості навчання англійської мови. Національний технічний університет України “Київський політехнічний інститут імені Ігоря 
Сікорського", 2007. URL: https://kpi.ua/1012-8 (дата звернення: 28.04.2021).

6. Стратегія розвитку вищої освіти в Україні на 20212031 роки. Міністерство освіти і науки України. Київ, $2020.71 \mathrm{c}$.

7. Тарнопольський О.Б., Кабанова М.Р. Методика викладання іноземних мов та їх аспектів у вищій школі: підручник. Дніпро: Університет імені Альфреда Нобеля, $2019.256 \mathrm{c}$.

8. Финогенова О.Н., Денисенко Ф.Н. Мотивация к изучению иностранного языка магистрантов инженерных специальностей. Современные исследования соииальных проблем. 2018, Том 9, № 11. C. 190-207. DOI: 10.12731/2218-7405-2018-11-190-207

9. Dornyei Z. The Psychology of the Language Learner: Individual Differences in Second Language Acquisition. Lawrence Erlbaum Associates Publishers. 2005. 270 p.

10. Nurhidayah R. The role of motivation in second language acquisition. Jurnal Ilmiah Spectral. Vol 6, No. 2 (2020) pp. 96-104.

11. OECD. Trends Shaping Education 2019. OECD Publishing, Paris, 2019. DOI: https://doi.org/10.1787/ trends_edu-2019-en

12. Quora. How do you stay motivated while learning a language? 2021. URL: https://www.quora.com/How-doyou-stay-motivated-while-learning-a-language (дата звернення: 28.04.2021).

13. Quora. What are your motivations in learning a new language? 2016. URL: https://www.quora.com/Whatare-your-motivations-in-learning-a-new-language (дата звернення: 28.04.2021).

\section{REFERENCES}

1. Bolayto, R. \& Vest, R. (2017). Internatsionalizatsiya ukrayinskykh universytetiv u rozrizi anhliyskoyi movy: Proekt "Anhliyska mova dlya universytetiv" [Internationalization of Ukrainian Universities in the English Language: Project "English for Universities"]. Kyiv, 154 p. [in Ukrainian].

2. Ministry of Education and Science of Ukraine (2019). Kontseptsiia rozvytku anhliiskoi movy v Universytetakh [The concept of English language development at Universities]. Available at: https://mon.gov.ua/ua/news/ mon-stvorilo-koncepciyu-rozvitku-anglijskoyi-vuniversitetah-u-dodatku-riven-v1-obovyazkova-umovavstupu-v2-vipusku-vikladannya-profilnih-disciplininozemnoyu-ta-movni-skriningi (Accessed 28 April 2021). [in Ukrainian].

3. Kornytska, Y. (2020). Perevernutyi klas v kursi anhliiskoi movy fakhovoho spriamuvannia: stavlennia studentiv [Flipped classrom in the esp course: students' perceptions]. Youth and market. Monthly scientificpedagogical journal. Drogobych, Vol. 1/180, pp. pp. 116120. [in Ukrainian].

4. Morentsova, A.V. (2020). Samostiine ekstensyvne chytannia adaptovanykh knyh anhliiskoiu movoiu u nemovnykh vyshchykh navchalnykh zakladakh [Individual extensive reading of adapted books in English in non-linguistic universities]. Young Scientist. No. 4 (80), pp. 605-608. DOI: https://doi.org/10.32839/2304-5809/2020 4-80-125 [in Ukrainian].

5. Saienko, N.S. etc. (2007). Monitorynh yakosti navchannia anhliiskoi movy [Monitoring the quality of English language teaching]. National Technical University of Ukraine "Igor Sikorsky Kyiv Polytechnic Institute". Available at: https://kpi.ua/1012-8 (Accessed 28 April 2021). [in Ukrainian].

6. Ministry of Education and Science of Ukraine (2020). Stratehiia rozvytku vyshchoi osvity v Ukraini na 20212031 roky [Strategy for the development of higher education in Ukraine for 2021-2031]. Kyiv, 71 p. [in Ukrainian].

7. Tarnopolskyi, O.B. \& Kabanova, M.R. (2019). Metodyka vykladannia inozemnykh mov ta yikh aspektiv u vyshchii shkoli: pidruchnyk [Methods of teaching foreign languages and their aspects in higher education: coursebook]. Dnipro: Universytet imeni Alfreda Nobelia, 256 p. [in Ukrainian].

8. Finogenova, O.N. \& Denisenko, F.N. (2018). Motivatsiya $\mathrm{k}$ izucheniyu inostrannogo yazyka magistrantov inzhenernykh spetsialnostey [Motivation of master's degree students of engineering programme to learning foreign languages]. Modern Studies of Social Issues. Vol. 9, No. 11, pp.190-207. [in Russian].

9. Dornyei, Z. (2005). The Psychology of the Language Learner: Individual Differences in Second Language Acquisition. Lawrence ErlbaumAssociates Publishers. 270 p. [in English].

10. Nurhidayah, R. (2020). The role of motivation in second language acquisition. Jurnal Ilmiah Spectral. Vol 6, No 2, pp. 96-104.[in English].

11. OECD (2019). Trends Shaping Education 2019. OECD Publishing, Paris. DOI: https://doi.org/10.1787/ trends_edu-2019-en[in English].

12. Quora (2021). How do you stay motivated while learning a language? Available at: https://www.quora.com/ How-do-you-stay-motivated-while-learning-a-language (Accessed 28 April 2021). [in English].

13. Quora (2016). What are your motivations in learning a new language? Available at: https:/www.quora.com/ What-are-your-motivations-in-learning-a-new-language (Accessed 28 April 2021). [in English].

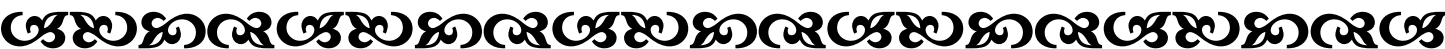

"У міння ставити розумні запитання вже є важлива $i$ необхідна ознақа розуму $i$ проникливості".

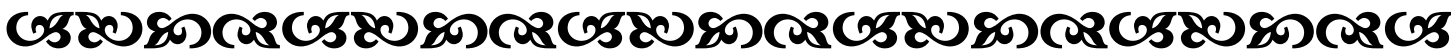

